\title{
Pandemic in the network society: Network readiness increases population vulnerability to COVID-19 in less developed countries
}

\author{
VLADIMIR D. MILOVIDOV ${ }^{1,2 *}$ (1)
}

\begin{abstract}
${ }^{1}$ Moscow State Institute of International Relations (MGIMO University), School of International Economic Relations, International Finance Department, 76, Prospect Vernadskogo, 119454, Moscow, Russian Federation

${ }^{2}$ Institute of World Economy and International Relations of Russian Academy of Science, Moscow, Russian Federation
\end{abstract}

Received: March 21, 2021 • Revised manuscript received: August 1, 2021 • Accepted: August 15, 2021

(C) 2021 Akadémiai Kiadó, Budapest

\begin{abstract}
This paper examines the factors which determine the impact of network communication and network connections on the likelihood of contracting the new coronavirus in the European and Latin American countries. The author presents several data sets to prove the following suggestions: 1) The generalized indicators of economic development and society's globalization are not indicators of how vulnerable a country's population may be in a pandemic; 2) Not the economy as such, but the conventional way of life of people, their daily behaviour and habits have a decisive influence on the disease spread; 3) Factors of prevention of illness and health promotion such as the habit of exercise, distance, and network communications use modern online services to become protective factors against the risk of infection only at a certain level of development of the country; 4) In the developed countries, a much broader set of factors than in the developing countries determine protection against disease risk; 5) The evolution of a networked society opens up significant opportunities for the developing countries to improve the quality of life, and the emergence of new, progressive traditions.
\end{abstract}

\section{KEYWORDS}

COVID-19, Europe, exponentially scalable events, globalization, information technology

\section{JEL CLASSIFICATION INDICES}

D85, E21, F15, F60, I15, I31, 030, 052, 054, P52

*Corresponding author. E-mail: vmilovidov@hotmail.com 


\section{INTRODUCTION}

The COVID-19 pandemic will leave an indelible mark on people's lives in all countries, without exception, since it has some distinctive features in comparison with previous pandemics of the $20^{\text {th }}$ and early 21 centuries.

Firstly, the current pandemic can rightfully be considered the most significant biological catastrophe in the developed post-industrial society that has reached a very high degree of globalization. The officially recorded number of worldwide infections runs over 200 million, but it is widely believed that the true number (including the not recorded cases) are much higher. Two substantial epidemics of the "Asian flu" in 1957-1958 and the "Hong Kong flu" in 1968 fell on the early post-war stage of forming this society. The swine flu pandemic in 2009 took place in the context of globalization, too. Still, they all turned out to be significantly less consequential than the scale and consequences of infection with a new coronavirus infection.

Secondly, compared with the previous examples, the current pandemic happens in a world economy, which is at the highest historical point of prosperity. The "Spanish flu" broke out during the First World War, the "Asian flu" coincided with the economic crisis, the "Hong Kong flu" - with the war in Vietnam (1968-1969), and the "Swine flu" followed the global financial crisis. The eve of 2020 could not be called completely quiet and calm. Still, the scale of the material, financial, energy, and intellectual resources accumulated in the world is difficult to compare with those that the world had 50-60 years ago, and even more so 100 years ago. Trends in the internationalization of economic relations and the transnational activities of financial and industrial companies, the development of international value chains, and the formation of a global labor market provided a seemingly solid foundation for long-term and sustainable economic growth. It is impossible to deny the progress in the development of the social sphere, health care, and the service sector, which also could not but contribute to an increase in the general level and quality of life on the planet. All these achievements were supposed to help the world community minimize pandemics' risks and consequences. However, the 2020 pandemic experience showed that the benefits of a high development level did not protect tens of millions of people from the new disease's dire consequences.

Thirdly, the pandemic coincided with a great new round of the technological revolution. Whether in the past periods of human history, technological transformations were mostly industrial innovations, today they directly cover the sphere of citizens' personal life and interpersonal communication. Development of technologies for processing big data, information exchange, online services to deliver goods, social networks, and artificial intelligence helps spread public relations beyond the normal physical state and regional boundaries. The global online society involves a lot of small communities and neighborhoods. Previously, they did not have the slightest chance of breaking free from their local isolation. At present, the population's awareness and efficiency in obtaining data are growing, and the exchange of knowledge and experience between people is intensifying. All of this can help ensure a safe and healthy lifestyle. Simultaneously, the expansion of network communication and global mobile applications affect people's physical contacts in real life. Development of horizontal structures over the traditional vertical organization of social relations and economic activity makes it possible to speak of modern post-industrial society as a developed network society, more integrated, interconnected and interdependent. At critical moments in the emergence of new dangers and threats, this can be a blessing, or it can turn into a chain reaction of the global problems. 
How do the achieved level of social welfare and the scale of a network society's development affect human life safety? Are they good or evil in providing people with additional protections against the risks of pandemics? Finding answers to these questions seems very important since disruptive innovations accompany network society's evolution and can become catalysts for as yet unknown exponentially scalable consequences, including the catastrophic ones. The present author is firmly convinced that, firstly, there is no uniformity of reasons for the greater or lesser likelihood of infection of different countries with the COVID virus. Secondly, there is regionalization of the consequences of the development of a global network society. In such a way, the same achievement can positively affect one region and may have a negative effect on another one. Thirdly, a high level of development of a network society turns out to be the most effective in ensuring biological safety in the countries with a higher standard of living, which retain their regional and cultural specifics and robust local communities.

This article is a continuation of the author's research for identifying exponentially scalable events (ESE) capable of causing significant transformations of socio-economic, political relations and institutions (Milovidov 2015, 2018). The development of global information and communication network technologies are examples of such ESE. In various situations, especially in the context of social, economic, political crises, and natural and biological disasters, the effect of their introduction into the everyday life of citizens can be very significant. In this article, using the example of Europe and Latin America's countries, the author proposes a comparative study of the impact of network society's development indicators on the spread of the COVID virus. The choice of regions for comparison is due to a certain similarity of their peoples' cultures and religions, their linguistic commonality, the scale of infection of the population with the new coronavirus, clearly expressed specificity and different economic development levels. The latter makes it possible to reveal the influence of factors of development of the network society on the spread of the epidemic with the level of public welfare.

The author undertakes the original idea to find the criteria for developing a networked society that affected coronavirus's spread by August 2020. The date was chosen according to the criterion of data novelty when preparing the first version of the preprint (Milovidov 2020). Subsequently, the author assessed the persistence of the identified trends as of other dates (Milovidov 2021). He noted that in the periods when pandemic waves in the countries under consideration are most synchronized, and the values of daily detected cases of the disease turn out to be as close as possible, the hypotheses expressed are confirmed most clearly. The first such date was October 1, 2020. Up to date another data for synchronization of pandemic waves was in late February-early March 2021. For this article's purposes, the author selected new data of synchronization of the pandemic waves, which is March 1, 2021.

\section{NETWORKS, GLOBALIZATION, AND COVID-19}

A significant amount of scientific work written on the development, structure and analysis of human network format allows us to formulate several important theses for further analysis.

-The network is the main form of social relations. A century ago, sociologists' main focus was on the study of groups, the process of their formation, the behaviour of their members, and intragroup and intergroup connections. The founder of network analysis, the German philosopher and sociologist Simmel (1995) depicted society as a web of groups of affiliated people. In 
his sociometric work, Moreno (1934) replaced the term "web” by "network". Graphical techniques for representing intergroup relationships emphasize this change. Moreno presents the network as a psychological structure with feedback when network participants unfamiliar with those in a distant network can influence one another. Moreover, he was one of the first to argue that networks have an architectonic function in society.

In the late $70 \mathrm{~s}$ - early $80 \mathrm{~s}$ in the sociological literature, the use of the term "networks" became more and more widespread. Granovetter (1973) attempted to reveal the strength of various network connections, Feld (1981) applied the focused theory of network formation and looked for the main "foci" of the group, that is the main idea or motive which determines the group affiliation. According to Freeman (2004), the growth of publications on social network issues became especially noticeable since the end of the 80 s of the last century. In the 90 s - early 2000s, the idea that the world is a network was finally established (Carpa 1997; Wellman 2001). J. McNeil - W. McNeil (2003) used the concept of a network as the dominant form of society's organization as a starting point for their study of human history.

The evolution of the terminology of network society research is confirmed statistically. Figure 1 shows the dynamics of mentions of the terms "web," "group," "global," "net," "network" in English literature since 1900 per 1 million words. As we can see, at the beginning of the XX century, the term "net" was the most used, the term "group" was close to it in popularity, and the term "web" was the third on the top. The 50s became the turning point when the trends changed and the terms "global" and "network" began to gain popularity simultaneously, while the term "net" was losing it.

- The network has fundamental differences from social groups. First of all, the network is a horizontal structure of connections in society. Instead, groups are more traditional forms of human interaction within hierarchical structures. Groups admit boundaries, internal and external hierarchy, the stability of contacts between group members among themselves. In networks, we see a different picture. There are no constant and unchanged borders, typically peer-to-peer relations, and the hierarchy "can be flatter and recursive" (Wellman 2001; Lovink 2020).

- The networks are becoming an integral part of the global society. The simultaneously rising popularity of the terms "global" and "network" (Fig. 1) confirms it. The idea of parallelism between developing a networked society and globalization we find in the pioneered works of van Dijk (2006) and Castells (2005). The former called societies in countries such as China and India post-industrial networked societies, the latter noted that the networked society is global and based on global networks.

- One of the characteristics of networks is their so-called performativity, namely, the ability of the network itself not only to acquire its qualitative features, which are not characteristic of its elements or participants but also to exert a feedback effect on them (Apprich 2020). In the words of Latour's actor-network theory, the network becomes a social actor, and not just a channel for information, feelings, knowledge and actions. The network gives additional meaning to those relationships that bind their participants; it can modify these relationships, and, therefore, influence the actions, state and behaviour of the participants, which are many people in various countries and regions of the world (Joo - Teng 2017; Parvez et al. 2019).

- Networks play an essential role in determining specific social processes or events. This role becomes especially noticeable in critical situations, at times of crises, including biological 


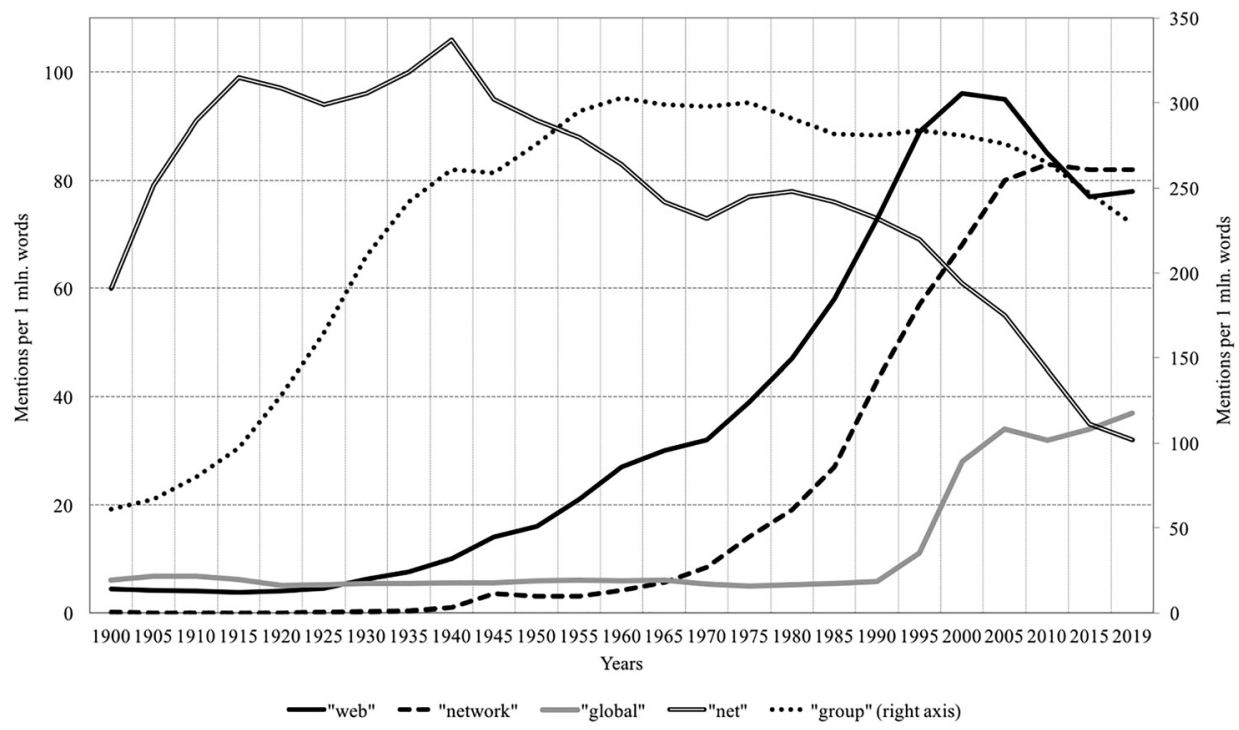

Fig. 1. The popularity of using the terms in English literature in 1900-2019, mentions per $1 \mathrm{mln}$. words Source: Google Ngram Viewer.

disasters, such as pandemics. It is quite logical that a separate independent direction of modern attempts to combine medicine and sociology is the study of networks' role in ensuring citizens' health. Networks contribute to the dissemination of information about current events, about the response to them, they show themselves as indicators of the mood and the scale of the spread of diseases, including the new coronavirus (Christakis - Fowler 2007, 2009, 2010; Perkins et al. 2015; Jia et al. 2020).

We can make an initial assumption: the level of globalization and the development of a networked society should have and already have influenced the dynamics of the COVID virus diseases in various countries of the world. Another thing is that this influence could be extremely heterogeneous, with a pronounced regional specificity and depends on the mass of factors that intensified this influence and weakened it.

Before moving on to identifying the specifics and features of the influence of the networked society on the features of the pandemic in various countries of the world, we will try to assess it at the level of the most generalized indicators. Let us take five indices that measure in different ways the degree of development of a society, the level of its globalization and connectedness of people in different countries of the world:

1. The globalization index, calculated by the KOF Swiss Economic Institute (KO-GI),

2. The Network readiness index (NRI), calculated by the Portulans Institute since 2019,

3. The Global Connectedness Index, derived by DHL (GCI DHL),

4. The Global Health Security Index (GHSI), a project of the Johns Hopkins Center for Health Security and the Nuclear Threat Initiative, a non-profit organization, and derived by The Economist Intelligence Unit. 


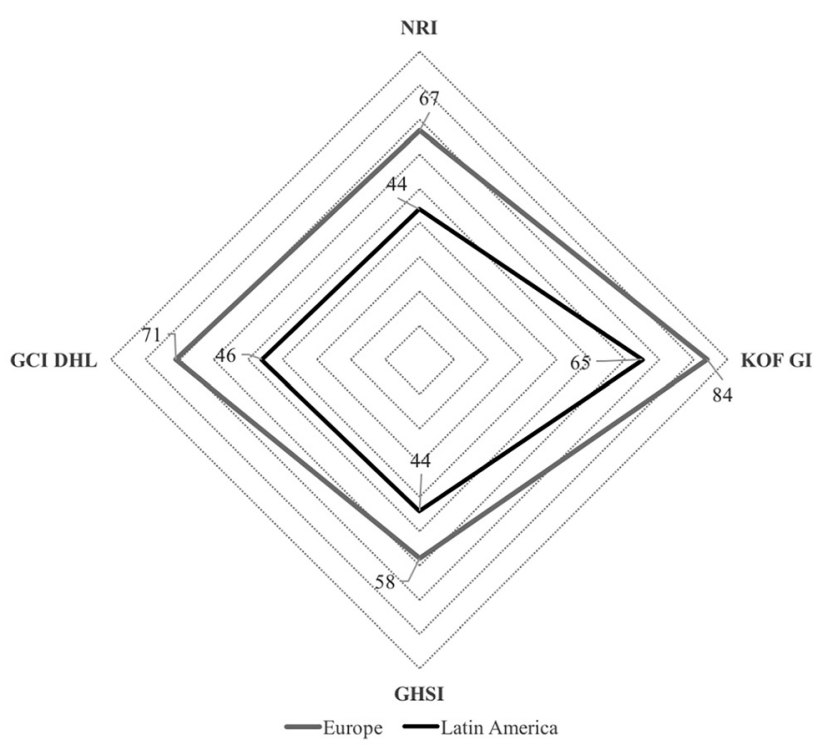

Fig. 2. Comparison of average scores of various indices in Europe and Latin America

Source: KO-GI 2020, https://kof.ethz.ch/en/forecasts-and-indicators/indicators/kof-globalisation-index. html; NRI 2020, https://networkreadinessindex.org; GCI-DHL 2020, https://www.dhl.com/global-en/ thome/insights-and-innovation/thought-leadership/case-studies/global-connectedness-index.html; GHSI 2019, https://www.ghsindex.org.

Methodologies of calculation these indexes are different. Meanwhile, they are the integral indicators of the countries' achievements in developing the modern means of communication and maturing the health care system and integrating into global value chains (Fig. 2).

To conduct a comparative analysis, we use two general indicators of COVID pandemic: the total number of people infected with the COVID virus and the average number of cases per 1 million population in 27 European and 18 Latin American countries. ${ }^{1}$ As of March 1, 2021, there were, on average, 50,360 cases per 1 million population of 27 European countries and 34,393 cases per 1 million people of 18 Latin American countries.

As expected, the scores of the selected indices for the European countries are not only higher than for the Latin American countries, but also more proportional to each other. The geometry of the lines shown on the chart emphasized it. The level of globalization of the Latin American countries (KO-GI 65) is disproportionately higher than the level of development of a networked society and a system for ensuring citizens' health. Moreover, in these countries, the NRI (44) and the GHSI (44) are equal. Could health protection and biological safety be directly proportional

\footnotetext{
${ }^{1}$ For Europe, they are Austria, Belgium, Bulgaria, Croatia, Cyprus, Czech Republic, Denmark, Estonia, Finland, France, Germany, Greece, Hungary, Ireland, Italy, Latvia, Lithuania, Luxembourg, Malta, the Netherlands, Poland, Portugal, Romania, Slovakia, Slovenia, Spain and Sweden. For Latin America, they are Argentina, Bolivia, Brazil, Chile, Colombia, Costa Rica, the Dominican Republic, Ecuador, Guatemala, Honduras, Mexico, Nicaragua, Panama, Paraguay, Peru, El Salvador, Uruguay and Venezuela.
} 
to the level of development of network communications and network society with all the resulting adverse consequences for the population? At least when comparing the average data on morbidity and globalization indices of the networked society, the conclusion suggests itself that the most networked countries in Europe 1) are less prepared in terms of protecting citizens from pandemics, 2) they have more suffered from an epidemic than the less developed networked societies of Latin America, despite the level of health security in these regions is considerably higher than in Latin America.

It means that the population of the most developed and networked countries are more vulnerable to pandemic. This conclusion requires a more detailed analysis of the factors that affect the epidemic's deployment in the selected countries.

\section{WEALTH OF THE NATIONS AND COVID PANDEMIC}

Advances in healthcare, the development of communications, social networks, the use of modern information technologies, and integration into global value chains result from a longterm economic development process. Consequently, the aggregate indicators of economic development, for example, the GDP or value-added produced in the service sector, both in absolute terms and per capita, should correspond to the scores that countries gain in the global indices calculation (KOF-GI, GHSI, NRI, GCI). So, we may suggest that we will observe the same relationship when comparing economic development indicators with indicators of the spread of COVID. Namely, the higher the level of economic development is, the more will be morbidity among the population. Table 1 provides the data.

Table 1. Indicators of socio-economic development in Europe and Latin America and cases of COVID (Million)

\begin{tabular}{|c|c|c|}
\hline & Europe (27 countries) & Latin America (18 countries) \\
\hline $\begin{array}{c}\text { Total number of cases of COVID (as of March } \\
\text { 1, 2021) mln. }\end{array}$ & 22.6 & 21.3 \\
\hline $\begin{array}{c}\text { Number of cases per 1 mIn. population (as of } \\
\text { March 1, 2021) }\end{array}$ & 50,360 & 34,393 \\
\hline GDP, current US \$, trn. (Latest data, 2019) & $15.6(0.84)^{*}$ & $4.99(0.89)^{*}$ \\
\hline $\begin{array}{l}\text { GDP, current US \$, per capita (Latest data, } \\
\text { 2019) }\end{array}$ & $34,897(0.11)^{* *}$ & $8,444(0.26)^{* *}$ \\
\hline $\begin{array}{c}\text { Services, value added, current US \$, trn. } \\
\text { (Latest data, 2017) }\end{array}$ & $10.1(0.86)^{*}$ & $3.0(0.94)^{*}$ \\
\hline $\begin{array}{c}\text { Services, value added, current US \$, per } \\
\text { capita (Latest data, 2017) }\end{array}$ & $22,633(0.09)^{* *}$ & $5,412(0.65)^{* *}$ \\
\hline
\end{tabular}

Sources: World Bank Data, Our World in Data.

Notes: * correlation between the value and total number of registered cases of COVID; ** correlation between the value and number of registered cases of COVID per $1 \mathrm{mln}$. population. 
When comparing the macroeconomic indicators for the two groups of countries, it is clear that in the most economically developed and wealthiest countries, the number of cases is more than in the developing countries. If we turn to the analysis of economic development indicators and the spread of the epidemic for each group of countries separately, we will see the same picture. Table 1 also presents the correlation coefficients between economic indicators and COVID cases for Europe and Latin America. To obtain these coefficients, we compare the total volume of produced GDP and services with the total number of cases and the relative indicators of economic development per capita with the number of cases per 1 million people.

Based on the calculations carried out, we see there is a positive relationship between the selected indicators. Thus, at the regional level, in a group of countries with approximately the same or similar economic development level, the number of diseases increased in absolute and relative terms in direct proportion to the increase in economic well-being. This conclusion is not unique. A study of 35 different socio-economic indicators in 72 countries (Stojkoski et al. 2020) clearly showed that the wealthier countries were more susceptible to the pandemic. A study of the characteristics of the spread of the disease in 6 cities in the United States (Benitez et al. 2020) partly confirmed this conclusion. The authors pointed to the racial and ethnic disparities in COVID. However, they noted that the socio-economic factors practically do not enhance it, in contrast to demographic factors, human and income mobility.

This phenomenon's possible explanations include a large proportion of the elderly population in the developed countries, more testing to detect infection. Also, the industrially developed and prosperous countries attract many migrants, and as a result, the concentration of low income and poor populations in such countries is growing. At the same time, most researchers agree that there is no unambiguous interpretation of the positive relationship between the level of socio-economic development and the spread of infection.

Differences in the correlation between the number of cases per million and economic indicators per capita in Latin America and Europe indicate the ambiguity of wealth and development factors in protecting populations from the epidemics risks. In Europe, we find a weak correlation between GDP per capita and illness cases per 1 million people (0.11). In Latin America this relationship is a little stronger (0.26). This occurs, probably since the economic development factors have a noticeable but indirect impact on health security and only from a particular moment when the effect of the achieved level of well-being extends to all aspects of society. In the developing countries, the socio-economic effect of GDP growth on quality of life is uneven, there is a profound social and property stratification, which leads to sharp differences in the way of life among the groups of wealthier and less wealthy citizens. That will weaken correlation.

The features of the way of life, people's behaviour, and habits are even more prominent in the foreground. These factors will be the subject of analysis in the next part of the article.

\section{REGIONALIZATION OF MODERN LIFE STANDARDS}

COVID affects the intensity of contacts between people, their visits to public places, and contribute to the development of immunity and ensure a healthy and comfortable lifestyle. We will focus on six lifestyle indicators (Table 2). 
Table 2. Life standards indicators in Europe and Latin America

\begin{tabular}{|l|c|c|}
\hline & Europe (27 countries) & Latin America (18 countries) \\
\hline $\begin{array}{l}\text { Number of cases per 1 mIn. population (as of } \\
\text { March 1, 2021) }\end{array}$ & 50,360 & 34,393 \\
\hline Household average size, members & 2,5 & 3,8 \\
\hline $\begin{array}{l}\text { Multi-generation households, \% of } \\
\text { population }\end{array}$ & $29^{*}$ & 32 \\
\hline Internet users, \% of population & 78 & 39 \\
\hline $\begin{array}{l}\text { Level of physical activity of adults, \% of } \\
\text { population }\end{array}$ & 45 & $34^{* *}$ \\
\hline Preferred interpersonal distance, cm & $104^{* * *}$ & $93^{* * * *}$ \\
\hline $\begin{array}{l}\text { Eating out-of-home population, \% of } \\
\text { population }\end{array}$ & $69.8^{* *}$ & $71^{* * * * *}$ \\
\hline
\end{tabular}

Sources: Household average size and composition, 2019 - United Nations, Department of Economic and Social Affairs, available at: https://population.un.org/Household/\#/countries/840; Physical activity of adults in EU Physical activity factsheets for the 28 European Union Member States of the WHO European Region, Overview, 2018, available at: https://www.euro.who.int/en/health-topics/disease-prevention/physical-activity/data-andstatistics/physical-activity-fact-sheets/factsheets-on-health-enhancing-physical-activity-in-the-28-eu-memberstates-of-the-who-european-region; Physical activity in Latin America - Celis-Morales et al. (2019), available at: https://www.sciencedirect.com/science/article/pii/S0716864019300410?via\%3Dihub; Preferred interpersonal distance - Sorokowska A. et al. (2017); Internet user - Our World in Data; Eating out-of-home - The Nielsen Company, available at: https://www.nielsen.com/wp-content/uploads/sites/3/2019/04/global-ingredient-andout-of-home-dining-trends-aug-2016.pdf.

Notes: * average for 7 countries; ${ }^{* *}$ average for 10 countries; ${ }^{* * *}$ average for 14 countries; ${ }^{* * * *}$ average for 4 countries; ${ }^{* * * *}$ average for 5 countries.

1. Average size of households, that is, the number of people living together. Household size can be related to the indicators of a particular country's cultural and national characteristics. The way of life as part of a large family, in one house, depends on the traditions of organizing social life, the family's role and significance, and the characteristics of close people's relationship. Due to these and many other factors, household size varies from country to country. As a rule, in the developed countries, this size is smaller than in the developing countries. In the European countries considered in the article, the average household has 2.5 members, and in Latin America 3.8.

2. Proportion of multigenerational households. Age differences among household members can affect the household's degree of vulnerability in an epidemic. In a study of the spread of infection in the UK (Mikolai et al. 2020), authors show the highest risk of contracting the virus in multigenerational households (39\% of households) and retirement-age households (40\%). Moreover, for $22 \%$ of multigenerational households and $44 \%$ of retirement-age households, they faced an increased risk of infection and problems with access to the Internet and other digital services. For the countries of Europe and Latin America, this is not the case. In the European countries, where we see a greater number of cases of COVID per $1 \mathrm{mln}$., the 
proportion of multigenerational households (29\%) is less than in the Latin American countries (32\%).

3. Internet access and the spread of digital services. Some researchers are currently paying attention to the Internet's unique role and social networks in a pandemic. Social networks can act as accelerators of the spread of specific behaviour, protecting a person from threats and increasing risks (Christakis - Fowler 2007). Networks play an important role in informing people about the dangers of infection (Block et al. 2020), which implies preventing the spread of various kinds of fakes and misinformation (Mourad et al. 2020). Analysis of social networks allows accumulating statistics of queries on the Internet and data on people's movement, which makes it possible to identify the foci of infection, especially the spread of infection (Christakis - Fowler 2010; Jia et al. 2020). Finally, the study of the networked society's structure, the scale and features of social networks in a particular country is also critical. According to several authors, network interaction's national and cultural characteristics become the factors of a greater or lesser spread of diseases (Perkins et al. 2015). In this case, the strength of local ties, local networks, where cultural, family, ethnic and regional ties are substantial, play a unique role (Maxwell et al. 2017). Meantime decreasing the use of the social network may increase offline contacts and interpersonal relations in real life, which may increase the risk of contamination (Allcot et al. 2019).

In the studied European countries, the average share of Internet users is $78 \%$ of the total population, and in Latin America 59\%. Does it mean that internet access is a factor of spreading the disease? This phenomenon has to be more addressed.

4. Physical activity of the population. Exercise can have a twofold effect on the spread of viruses in a given society. First, playing sports is, as a rule, an essential element of a specific culture of a healthy lifestyle, which may differ in different countries. Secondly, playing sports becomes a definite sign of belonging to a particular social group or network, in which active supporters of physical exercises regularly interact. They may share other mutual interests, themes and hobbies. Thirdly, depending on the type of exercise and sports that members of such networks or groups enjoy, this factor can increase infection risk. That may happen due to visits to public places for exercise, fitness rooms and sports clubs. An analysis of data for the European countries doesn't show any relation between the physical activity prevalence and the cases of illness. For Latin America, we see another picture.

At the level of interregional comparisons, we see that in Europe, there is a higher prevalence of exercise among the population than in Latin America, which is also coincide with illness proportion.

5. Interpersonal distance. Surveys of residents in 43 countries of the world regarding the distance they maintain when communicating with other people, both acquaintances and strangers, confirmed the well-known fact that the distance of interpersonal communication is a very characteristic indicator of the peculiarities of national culture, customs and local traditions (Sorokowska et al. 2017). Comparing the results of these studies with the statistics of the spread of infection shows a weak negative relationship between the corresponding values: the less the country's interpersonal distance, the more cases of the disease detected there (correlation -0.19). This result could be easily explained, however average data for Latin America and Europe as shown in Table 2 demonstrate a positive relationship. This fact is also a task for further studying. 


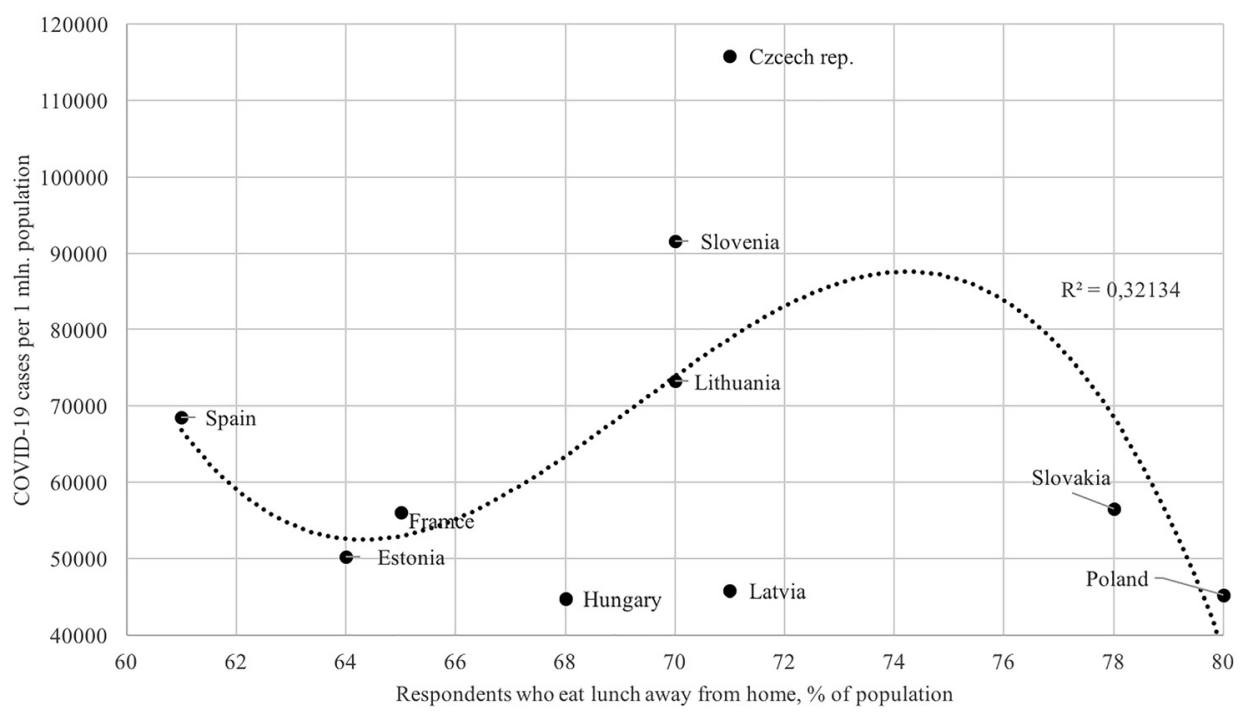

Fig. 3. Respondents who eat away from home and COVID cases in Europe Source: The Nielsen Company; Our World in Data.

6. Proportion of the population that prefers dining out. The pandemic of the novel coronavirus has severely impacted people's normal daily activities such as shopping and eating. The desire to maintain a distance and protect oneself from infections has led to a broader use of various online services. Nevertheless, the organization of people's daily life remains an essential factor in the probable infection in a pandemic. It is these behaviours that we will discuss in more detail below. What attracts attention first of all? In terms of the popularity of eating out, Latin Americans are not inferior to Europeans. On average, 69\% of Europeans and $71 \%$ of LatinAmericans eat away from home (Nielsen Company 2016). However, in each region these figures have different relationship with the number of COVID cases per $1 \mathrm{mln}$. population (Figs. 3 and 4).

In Latin America, we see a stable positive relationship between the percentage of people eating out of home and those infected. Where more people tend to visit public places, the risk of infection is higher. In Europe, we see a mixed picture. In one country, a decline in illness rates has accompanied with the decline in the popularity of café and restaurant visits. In other countries, with growth of a popularity eat away from home we see growth on illness numbers. This difference indicates not only the regionalization of the peculiarities of people's life but also the peculiarities of the organization of society.

\section{GOODS AND EVILS OF NETWORKING}

There are many studies on the reasons for the association of people into specific groups and networks. The question of what brings people together within the networks or groups is not idle. 


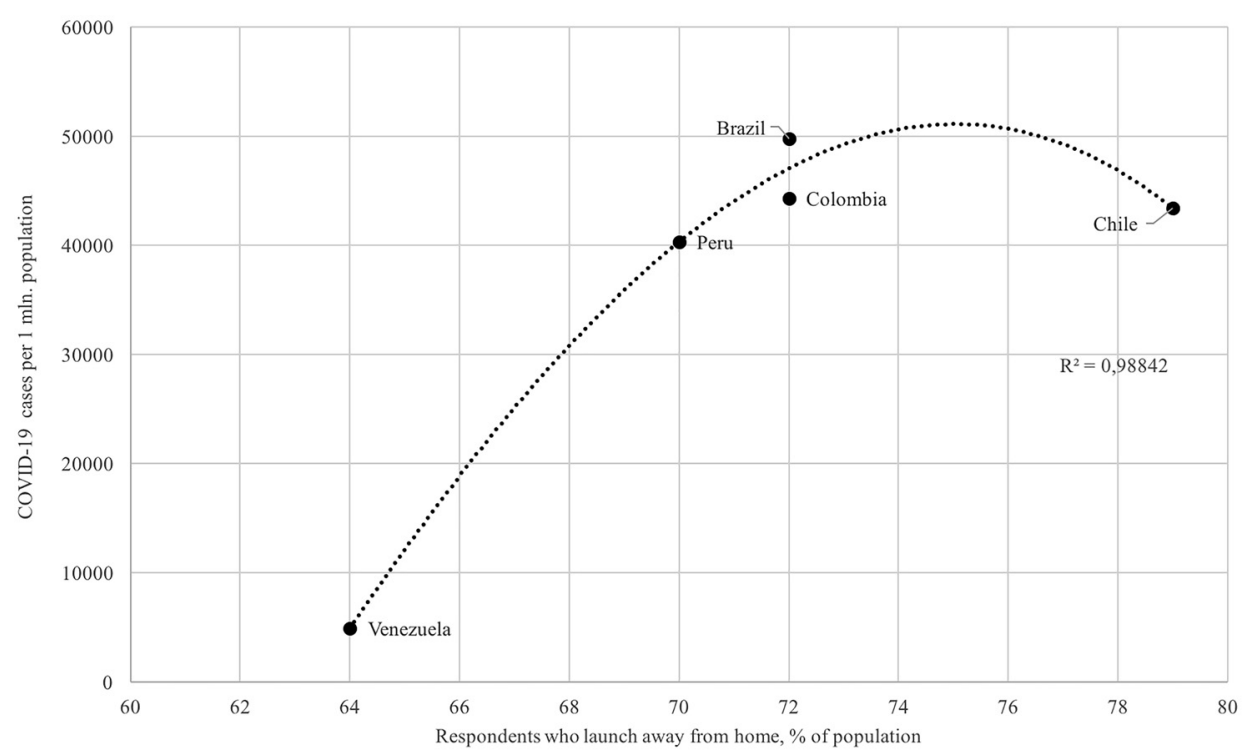

Fig. 4. Respondents who eat away from home and COVID cases in Latin America Source: As Fig. 3.

Feld (1981) proposed a "focused approach" to the analysis of social networks that helps to identify some common "foci" for their members. According to his study, the commonality of "foci" determines the similarity of behaviour, preferences, choices, opinions and subsequent actions. We will use this approach to identify people's lives' characteristics and the strength of their influence on the spread of the pandemic in various countries.

As shown above, the organization of consumption has significantly different effects on infection risk in the Latin American and European countries. In addition to eating out habits, let us look at the popularity of food delivery services and group countries based on which service is most popular there. We have two explanations for choice. First, higher popularity of online food ordering may indicate a lower likelihood of frequent visits to public places, such as shops, cafes and restaurants, and a higher likelihood of dining at home. This behaviour may reduce people's contacts and, consequently and hypothetically, to low the risks of diseases in an epidemic. Secondly, COVID pandemic has significantly pushed the development of food delivery services. This area not only attracts new investment and labour in all countries of the world, but it is also beginning to determine new trends in people's consumer preferences. The latter is extremely important in general for assessments and forecasts of economic development. The progress of this industry has its specific features in both developing and developed countries. Also, such services' distribution is an essential element in forming modern network society and people's networking.

To group countries and conduct a subsequent comparative analysis, we will select three regional food delivery networks in Europe: "Wolt" (first organised in Finland), "Deliveroo" (Great Britain), and "Glovo" (Spain), as well as in Latin America: "PedidosYa" (Uruguay), "Domicilios" and "Rappi" (Colombia). Each of these delivery services has become quite 
Table 3. Total COVID cases per $1 \mathrm{mln}$. population and level of network readiness in Europe and Latin America

\begin{tabular}{|c|c|c|c|c|}
\hline $\begin{array}{l}\text { Countries group by } \\
\text { number of total } \\
\text { COVID cases per } 1 \\
\text { mIn. population }\end{array}$ & $\begin{array}{l}\text { Total COVID cases } \\
\text { per } 1 \mathrm{mln} \text {. population } \\
(01.03 .2021)\end{array}$ & $\begin{array}{l}\text { Average score (of } \\
\text { five indicators) }\end{array}$ & $\begin{array}{l}\text { Network } \\
\text { Readiness } \\
\text { Index }\end{array}$ & $\begin{array}{l}\text { Most preferable food } \\
\text { delivery service and } \\
\text { its world popularity }\end{array}$ \\
\hline $\begin{array}{l}\text { EU countries group, } \\
\max \end{array}$ & 56,104 (max) & $56.6(\min )$ & 60 (min) & Glovo (intermediate) \\
\hline $\begin{array}{l}\text { EU countries group, } \\
\text { min }\end{array}$ & $41,418(\min )$ & $\begin{array}{c}64.40 \\
\text { (intermediate) }\end{array}$ & 66 (max) & Wolt (min) \\
\hline $\begin{array}{l}\text { Latin America's } \\
\text { countries group, } \\
\max \end{array}$ & 34,934 (max) & 40.6 (max) & 47 (max) & Rappi (max) \\
\hline $\begin{array}{l}\text { Latin America's } \\
\text { countries group, } \\
\text { min }\end{array}$ & $29,193(\min )$ & $\begin{array}{c}32.4 \\
\text { (intermediate) }\end{array}$ & 40 (min) & PedidosYa (min) \\
\hline
\end{tabular}

Sources: Google trends; Our World in Data.

widespread in its region and globally, although its popularity in the world market is not the same. According to the search queries data (last 12 months) accumulated by Google (Google Trends), among the European delivery services, the most famous in the world is "Deliveroo", in second place is "Glovo" and in third place is "Wolt". Among the Latin American services, the most famous in the world is "Rappi", in second place is "Domicilios", in third place is "PedidosYa”.

Now let us consider which delivery service is most prevalent in a particular country in Europe and Latin America. Popularity over 50 on the Google Trends scale is a criterion for assigning a country to a particular group. As a result, three groups of countries are formed in each region, depending on the popularity of Google's inquiries for a food delivery service.

Having divided the countries of Latin America and Europe into three groups, we determine each of the groups' average values of the network society's development indicators. For these purposes, we use the network readiness index score for each country and its sub-scores, including: network readiness index for individuals (Individuals sub-pillar of NRI), households with internet access, active mobile-broadband subscribers, and internet shopping. Each of these five indicators determines the total network readiness index for every country and measures the degree of business and individual access to networks in that country and the penetration of digital technologies into economic and social activities. We combine these data with average number of cases of COVID per 1 million population in Table 3.

As we can see from this comparison, the Latin American countries have the lowest disease rates ( $\mathrm{min}$ ) in the least developed countries in terms of network readiness (min). The largest number of cases $(\max )$ occurs in the countries with maximum networking index. Also, in the countries least affected by the epidemic and with the least network development level, the least popular delivery service in the world is used out of the three regional services (PedidosYa). 
Furthermore, in the countries with the most cases of COVID, the Latin American delivery service (Rappi), the most known in the world, dominates there.

In Europe, we see a different picture. The maximum number of cases per 1 million people $(\max )$ occurs in the countries with minimum networking index (min). In this group of countries among the population and Latin America, a food delivery service is popular, which is characterized by an intermediate degree of popularity in the world (Glovo). In the group of European countries with the lowest number of cases of COVID per 1 million people ( $\mathrm{min}$ ), the picture is also opposite to those is in Latin America. The networked society's highest level of development $(\max )$ and the intermediate aggregate network readiness index score occurs in these countries. The choice of food delivery services by the population here is similar to what we see in Latin America. This choice falls on the world's least-known delivery service (Wolt).

Thus, in the developed countries, the higher the level of development of network communication and network connections is, the lower is the risk of contracting a new virus in a pandemic. In the developing countries, those most protected from pandemics are those where the network society's development level is minimal. These are the least developed countries in their region. The presented analysis suggests that the practical impact of network communications and networks on people's quality of life and health can be achieved only under certain conditions and at a particular stage of social development. The rapid pace of adopting network technologies in societies with a high degree of social stratification, low level of economic development, and more open and integrated into the global economy will likely increase risks. Without a qualitative and comprehensive improvement in living standards, new network communication formats increase people's vulnerability in epidemics.

\section{CONCLUSION}

This paper examined the factors determining the impact of network communication and network connections on the likelihood of contracting a new coronavirus in the European and Latin American countries. However, the results of the data analysis indicate the direction of further research only, but do not allow one to draw exhaustive conclusions about all the causal relationships and mechanisms of the influence of the development of a networked society on the quality of life of people and their degree of vulnerability in a pandemic. Nevertheless, we can make some conclusions, as follows:

1. The generalized economic development indicators and society's globalization are not indicators of how vulnerable a country's population may be in a pandemic. As the COVID pandemic experience shows, the most developed countries' population was the first to be affected by the spread of the new coronavirus.

2. Not the economy as such, but the conventional way of life of people, their daily behaviour and habits have a decisive influence on disease spread. However, this influence is highly contradictory and makes it possible to reveal any noticeable dependencies and trends.

3. Such factors of protection and health promotion as the habit of exercise, distance, and network communications use modern online services to become protective factors against the risk of infection only at a certain level of development of the country. In the less developed countries, these factors can play an opposite, damaging role. 
4. In the developed countries, a much broader set of factors determine protection against disease risk than in the developing countries. For the developing countries, the globalization of society and economy, the growth of their openness, and the rapid development of network communications are becoming a risk factor. That means governments of developing countries must develop appropriate mechanisms to protect and contain the negative consequences of their transition to a higher development level. First of all, they have to shorten the transition period, both economically and especially in the social sphere.

5. The evolution of a networked society opens up significant opportunities for the developing countries, improved quality of life, and the emergence of new traditions. All this together changes the established social structures, groups and local networks. The world is becoming more interconnected and interdependent. That will require collective efforts from the entire world community to equalize the living standards of the population in various countries of the world, which is a prerequisite for minimizing risks during the periods of global pandemics and possibly other biological crises.

\section{REFERENCES}

Allcott, H. - Braghieri, L. - Eichmeyer, S. - Gentzkow, M. (2019): The Welfare Effects of Social Media. Stanford Institute for Economic Policy Research (SIEPR) Working Paper, No. 19-002, January. https:// siepr.stanford.edu/research/publications/welfare-effects-social-media.

Apprich, C. (2020): The Never-Ending Network: A Repetitive and (thus) Differentiating Concept of Our Time. In: Gansing, K. - Luchs, I. (eds): The Eternal Network. The Ends and Becomings of Network Culture. Amsterdam, Berlin: Institute of Network Cultures, pp. 24-32.

Benitez, J. A. - Courtemanche, Ch. J. - Yelowitz, A. (2020): Racial and Ethnical Disparities in COVID-19: Evidence from Six Large Cities. NBER Working Paper, No. 27592.

Block, P. - Hoffman, M. - Raabe, I. J. - Dowd, J. B. - Rahal, C. - Kashyap, R. - Mills, M. C. (2020): Social Network-Based Distancing Strategies to Flatten the COVID-19 Curve in a Post-Lockdown World. Nature Human Behavior, 4: 588-596.

Carpa, F. (1997): The Web of Life. Schrodinger Lecture, Dublin, September $9^{\text {th }}$. https://www. semanticscholar.org/paper/The-Web-of-Life-Capra/bfb6c6a3bdfb66ad7016b6a43e18cc213bb0556b.

Castells, M. (2005): The Network Society: from Knowledge to Policy. In: Castells, M. - Cardoso, G. (eds): The Network Society from Knowledge to Policy. Washington, DC: Johns Hopkins Center for Transatlantic Relations, pp. 3-20.

Celis-Morales, C. - Rodriguez-Rodrigues, F. - Martinez-Sanguinetti, M. et al. (2019): Prevalencia de inactividad física en Latinoamérica ¿Logrará Chile y el Cono Sur reducir en un 10\% los niveles de inactividad física para el año 2025? (Prevalence of Physical Inactivity in Latin America - will Chile and the Southern Cone Succeed Reduce by 10\% the Levels of Physical Inactivity for the Year 2025?) Revista Medica Clinica Las Condes, 30(3): 236-239.

Christakis, N. A. - Fowler, J. H. (2007): The Spread of Obesity in a Large Social Network over 32 Years. The New England Journal of Medicine, July 26: 370-379.

Christakis, N. A. - Fowler, J. H. (2009): Social Network Visualization in Epidemiology. Norsk Epidemiologi, 19(1): 5-16. 
Christakis, N. A. - Fowler, J. H. (2010): Social Network Sensors for Early Detection of Contagious Outbreaks. PloS One, 5(9). https://journals.plos.org/plosone/article?id=10.1371/journal.pone.0012948. Feld, S. L. (1981): The Focused Organization of Social Ties. The American Journal of Sociology, 86(5): 1015-1035. Freeman, L. C. (2004): The Development of Social Network Analysis. A Study in the Sociology of Science. Vancouver, BC Canada: Empirical Press.

Granovetter, M. S. (1973): The Strength of Weak Ties. The American Journal of Sociology, 78(6): 1360-1380. Jia, J. S. - Lu, Xin - Yun, Y. - Xu, G. - Jia, J. - Christakis, N. A. (2020): Population Flow Drives SpatioTemporal Distribution of COVID-19 in China. Nature, 582: 389-394.

Lovink, G. (2020): Requiem for the Network. In: Gansing, K. - Luchs, I. (eds): The Eternal Network. The Ends and Becomings of Network Culture. Amsterdam, Berlin: Institute of Network Cultures, pp. 102-115.

Maxwell, D. - Stites, E. - Robillard, S. - Wagner, M. (2017): Conflict and Resilience: A Synthesis of Feinstein International Center Work on Building Resilience and Protecting Livelihoods in Conflict-Related Crises. Somerville, MA: Feinstein International Center, Tufts University.

McNeil, J. R. - McNeil, W. H. (2003): The Human Web. A Bird's-Eye View of World History. New York, London: W.W. Norton \& Company.

Mikolai, J. - Keenan, K.- Kulu, H. (2020): Intersecting Household Level Health and Socio-Economic Vulnerabilities and the COVID-19 Crisis: An Analysis from the UK. SSM-Population Health, 2 July.

Milovidov, V. D. (2015): Risk Management Under Informational Asymmetry: To Differentiate Those Distinguishable. World Economy and International Relations, 8: 14-24.

Milovidov, V. D. (2018): Hearing the Sound of the Wave: What Impedes One's Ability to Foresee Innovations? Foresight and STI Governance, 12(1): 88-97.

Milovidov, V. D. (2020): Pandemic in the Network Society. The Comparative Analysis of COVID-19 Spreading Features in Europe and Latin America. SSRN: https://ssrn.com/abstract=3683358 or http:// dx.doi.org/10.2139/ssrn.3683358.

Milovidov, V. D. (2021): Pandemic in the Network Society: COVID-19 in Europe and Latin America. Sovremennaya Evropa, 1: 130-140.

Moreno, J. L. (1934): Who Shall Survive? A New Approach to the Problem of Human Interrelations. Washington, DC.: Nervous and Mental Disease Publishing Co.

Mourad, A. - Srour, A. - Harmanani, H. - Jenainati, C. - Arafeh, M. (2020): Critical Impact of Social Networks Infodemic on Defeating Coronavirus COVID-19 Pandemic: Twitter-Based Study and Research Directions. https://arxiv.org/abs/2005.08820.

Nielsen Company (2016): What's in Our Food and on Our Mind. Ingredients and Dining-Out Trends Around the World. Report.

Parvez, S. - Rahaman, A. - Fatema, K. - Monds, D. R. (2019): Impact of Social Networking Sites on Interpersonal Relationship among Teenager: A Sociological Analysis in the District of Bagerhat. British Journal of Arts and Humanities, 1(5): 14-27.

Perkins, J. M. - Subramanian, S. V. - Christakis, N. A. (2015): Social Networks and Health: A Systematic Review of Sociocentric Network Studies in Low- and Middle-Income Countries. Social Science \& Medicine, 125: 60-78.

Simmel, G. (1955): Conflict. The Web of Group-Affiliations. The Free Press.

Sorokowska, A. - Sorokowski, P. - Hilpert, P. - Cantarero, K. (2017): Preferred Interpersonal Distances: A Global Comparison. Journal of Cross-Cultural Psychology, 48(4): 577-592.

Stojkoski, V. - Utkovski, Z. - Jolakoski, P. - Tevdovski, D. - Kocarev, L. (2020): The Socio-Economic Determinants of the Coronavirus Disease (COVID-19) Pandemic. https://www.medrxiv.org/content/ 10.1101/2020.04.15.20066068v1. 
Joo, T. M. - Teng, C. E. (2017): Impacts of Social Media (Facebook) on Human Communication and Relationships: A View on Behavioral Change and Social Unity. International Journal of Knowledge Content Development \& Technology, 7(4): 27-50.

van Dijk, J. (2006): The Network Society. Social Aspects of New Media. (Second ed.) London: SAGE Publications.

Wellman, B. (2001): Physical Place and Cyberplace: The Rise of Personalized Networking. International Journal of Urban and Regional Research, 25(2): 227-252. 